\title{
Why a hill country symposium?
}

G.A. KERR
Agriseeds, 2547 Old West Coast Rd, RD1, Christchurch 7671, New Zealand

gkerr@agriseeds.co.nz

\section{Introduction}

When I was young the hill country was where the store lambs came from. But with the flatter and generally better land being lost to the likes of urban and dairy farming expansion, New Zealand's hill country is now the key breeding platform, and is increasingly being required to finish stock for the red meat sector - a sector that generates nearly $\$ 8$ billion/year in export earnings for the country.

Hill country farmers, their service providers and local communities face notable challenges including continuing pressure on profitability, rural depopulation and climate change, as well as environmental pressure around the 'right to farm' from the greater New Zealand population. However, there are also great success stories in terms of the improvements in productivity and environmental stewardship that have been made in the hill country.

The Hill Country Symposium (HCS) will update relevant research and present some of the industry's successes. However, our main aim is as a group to answer two questions:

What does a profitable and resilient future for our hill country farming look like?

What do we, collectively and as individuals, need to do to achieve this future?

\section{What size is the hill country?}

Around $37 \%$ of New Zealand's total land area, or 10 million ha is classified 'hill country', that is, land with slopes greater than $15^{\circ}$ and below an altitude of 1000 metres a.s.1. Over half of this land (63\%) is in the North Island.

Around 5 million ha of this, or $18 \%$ of New Zealand's total area, is designated as pastoral hill country farm land.

Approximately 6000 farms are classified as hill country. About $80 \%$ of these in the North Island, averaging around 500 ha, with a typical stocking rate of 7.6-9.6 su/ha (Table 1). South Island hill country farms are larger (around 1600 ha average) with a much lower per hectare stocking rate and per hectare economic farm surplus.

\section{An individual farm}

Averages, however, hide the large variability that exists both between farms and within farms; 'variability' is a key concept when describing hill country farms. Like all farm enterprises, product prices, climate and weather are key variabilities. But hill country farms also have much greater variation in land class, slope, aspect, altitude and topography than flat land properties.

The hypothetical 'typical' hill country farm will have a limited amount, maybe $10-20 \%$, of flat to gently rolling land, which can be cultivated and used for crops and feed conservation. But the majority of the farm will be hill country with a slope greater than $15^{\circ}$, often much of which is not cultivatable, is expensive to fertilise with fixed wing aircraft, and is prone to erosion.

Also, there is much variability within paddocks, at

Table 1 Hill country farm statistics for 2013-14 season (Beef + Lamb New Zealand Economic Service).

\begin{tabular}{|c|c|c|c|c|c|c|c|c|}
\hline \multirow[b]{2}{*}{ Factor } & \multicolumn{2}{|c|}{ Upper North Island } & \multicolumn{2}{|c|}{ Taranaki-Manawatu } & \multicolumn{2}{|c|}{ East Coast } & \multicolumn{2}{|c|}{ South Island } \\
\hline & $\begin{array}{c}\text { Hill } \\
\text { Country }\end{array}$ & $\begin{array}{c}\text { Hard } \\
\text { Hill } \\
\text { Country }\end{array}$ & $\begin{array}{c}\text { Hill } \\
\text { Country }\end{array}$ & $\begin{array}{c}\text { Hard } \\
\text { Hill } \\
\text { Country }\end{array}$ & $\begin{array}{c}\text { Hill } \\
\text { Country }\end{array}$ & $\begin{array}{c}\text { Hard } \\
\text { Hill } \\
\text { Country }\end{array}$ & $\begin{array}{c}\text { Upper SI } \\
\text { Hill } \\
\text { Country }\end{array}$ & $\begin{array}{c}\text { Lower SI } \\
\text { Hill } \\
\text { Country }\end{array}$ \\
\hline Effective area (ha) & 345 & 586 & 434 & 922 & 549 & 944 & 1620 & 1496 \\
\hline Total labour units & 1.52 & 1.76 & 1.57 & 1.98 & 1.74 & 2.22 & 1.99 & 1.98 \\
\hline Total stock units (su) & 3385 & 4589 & 4083 & 7028 & 4775 & 7489 & 6408 & 6556 \\
\hline Stock units /ha & 9.8 & 7.8 & 9.4 & 7.6 & 8.7 & 7.9 & 4.0 & 4.4 \\
\hline Ewe lambing \% & 126.1 & 121.7 & 130.5 & 117.7 & 124.7 & 115.1 & 120.9 & 123.0 \\
\hline Shorn wool kg/sheep su & 5.19 & 5.58 & 5.89 & 5.41 & 5.46 & 4.47 & 4.38 & 4.59 \\
\hline Net Wool c/kg greasy & 336.8 & 342.2 & 337.4 & 335.0 & 347.3 & 337.1 & 411.7 & 408.0 \\
\hline Economic farm surplus $\$ /$ ha & 73.82 & 102.55 & 227.62 & 137.70 & 221.75 & 143.89 & 30.46 & 50.18 \\
\hline Economic farm surplus $\$ /$ su & 7.52 & 13.10 & 24.20 & 18.07 & 25.50 & 18.14 & 7.70 & 11.45 \\
\hline
\end{tabular}


both a macro-topographical level (such as variations in slope or soil fertility through stock camp areas) and at a micro-topographical level, such as the variation between flatter sheep tracks, with better soil and effective rainfall, than steeper inter-sheep track areas within a slope.

Managing variability creates challenges, at times making decisions based on 'averages', whether it is applying fertiliser or deciding when to graze.

\section{Challenges faced}

New Zealand needs a hill country farming industry that is sufficiently profitable and has the ability to both change to meet and at times simply withstand, the challenges it faces as well as make a fair return on capital given the risk of the investment. However, while the balance sheets of hill country farms are typically strong, with relatively low debt levels, the profit and loss statements are weak. Profitability is being squeezed by input costs rising faster than prices received for product.

Resilience in hill country systems is critical, particularly in view of climate change predictions of more frequent droughts and high intensity storms.

It has been said that the fundamental asset at the heart of hill country enterprises, the land and its infrastructure, is in a state of slow but steady decline. The questions this raises are how robust are those components and can we arrest this decline?

Continued improvement is required and a key challenge to this is the lack of research and development, extension and services to support and give confidence for change. This is important as hill country enterprises are often risk-averse as a consequence of income volatility.

Whether we have the skilled people needed for the future is also a challenge, accentuated by the continual rural depopulation both on farms and in communities in hill country areas.

Environmental issues such as erosion, water quality and greenhouse gases also need to be addressed, and there will likely be increasing limits made on the 'right to farm' by the wider New Zealand population.

\section{Successes}

Balancing the challenges there are also successes, which need to be celebrated.

Hill country farming has always faced a range of challenges, and one of its key strengths is the farmers and practitioners in the industry, and their ability to survive, adapt and improve productivity. In the last 25 years New Zealand's ewe numbers have dropped by $50 \%$, to around 20 million, but total lamb production has dropped by only $6.2 \%$ (to 370000 tonnes).

Individual hill country farms have also innovated in terms of pasture species, animals, monitoring and information systems (in which precision agriculture is included), alternative income streams, and how environmental issues are tackled. Over the next 2 days a number of these success stories will be discussed.

\section{Opportunities}

There are opportunities both on- and off-farm for New Zealand's hill country. As an iconic part of our country's social and visual landscape, there are opportunities to create and supply products which better meet buyer preferences, increase their willingness to pay, and thereby increase hill country farmers' strength in the value chain relative to other value chain participants.

\section{Aim of the Hill Country Symposium}

When this Symposium was put together it was decided to cover four parts: to review the science, to hear from farmers and other practitioners, to discuss what the future should look like, and finally, to condense thoughts raised throughout the Symposium into a position paper describing how best to ensure a profitable and resilient hill country is achieved.

\section{Science}

The Symposium will bring hill country research up to date in six areas from soils though to farm systems, including a range of review papers from leading scientists. It has been 23 and 25 years since the Gisborne and New Plymouth New Zealand Grassland Association Conferences, respectively, which were the last to have such a strong focus on hill country. So this Symposium is well overdue.

\section{Practitioners}

There are also presentations from farmers and other practitioners celebrating hill country success stories. In many cases on-farm practice has moved ahead of the research.

\section{Discussion about the future}

The final third of the Symposium is about discussing and helping set the direction, for the future of the hill country industry. What are the major challenges and opportunities? And what ideas, insights, research, support and work are needed to achieve a successful future?

To give balance to the discussions there will be a wide range of attendees including farmers, with a strong representation from Beef + Lamb New Zealand, a range of industry groups, scientists, consultants, resource managers, meat companies, agribusiness and policy makers.

To capture this there is time for questions in each of the first six sessions, as well as written feedback on each session. Tomorrow, session seven will involve delegates working in small groups, to make a contribution on the 
desired future of hill country farming and how to get there. This will be fed back to all delegates in session eight.

\section{Position paper}

So where will all this lead? The output of the Symposium will be captured formally as a position paper. This will be about the actions required rather than politics, and will be made available to industry, relevant agencies and policy makers to give guidance as to what the future for hill country needs to look like, the threats and opportunities, and the action required to get there.

\section{Conclusion}

The Organising Committee hopes you will find the 2-day
Hill Country Symposium stimulating, informative and interactive.

New Zealand's iconic hill country faces serious challenges into the future, but there have also been, and no doubt will continue to be, great success stories too.

The 5 million hectares of hill country farms is becoming the key red meat breeding platform, and is increasingly being used to finish stock. Currently, around $70 \%$ of lambs in New Zealand are born and weaned on hill country, and this figure is set to rise with the continual loss of land to urban expansion, dairying and other enterprises.

The purpose of the Hill Country Symposium is to work out what the future of hill country farming looks like, and how to get there. 